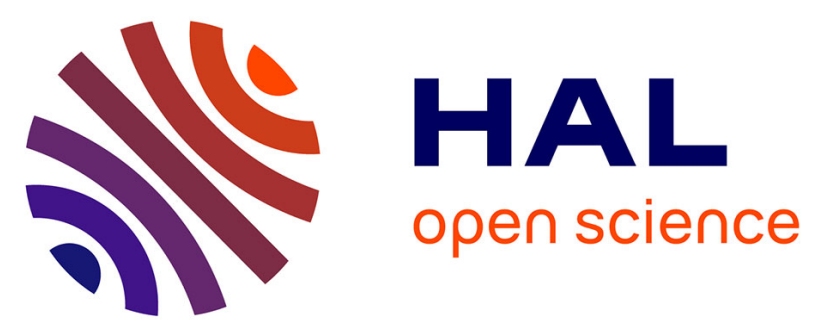

\title{
Spatially resolved catalysis in microstructured reactors by IR spectroscopy: CO oxidation over mono- and bifunctional Pt catalysts
}

C. Daniel, M. O. Clarte, S. P. Teh, O. Thinon, H. Provendier, A. C. van Veen, B. J. Beccard, Y. Schuurman, C. Mirodatos

\section{To cite this version:}

C. Daniel, M. O. Clarte, S. P. Teh, O. Thinon, H. Provendier, et al.. Spatially resolved catalysis in microstructured reactors by IR spectroscopy: CO oxidation over mono- and bifunctional Pt catalysts. Journal of Catalysis, 2010, 272 (1), pp.55-64. 10.1016/j.jcat.2010.03.012 . hal-00512047

\section{HAL Id: hal-00512047 \\ https://hal.science/hal-00512047}

Submitted on 4 Jan 2022

HAL is a multi-disciplinary open access archive for the deposit and dissemination of scientific research documents, whether they are published or not. The documents may come from teaching and research institutions in France or abroad, or from public or private research centers.
L'archive ouverte pluridisciplinaire HAL, est destinée au dépôt et à la diffusion de documents scientifiques de niveau recherche, publiés ou non, émanant des établissements d'enseignement et de recherche français ou étrangers, des laboratoires publics ou privés. 


\title{
Spatially resolved catalysis in microstructured reactors by IR spectroscopy: CO oxidation over mono- and bifunctional Pt catalysts
}

\author{
C. Daniel ${ }^{\text {a }}$, M-O. Clarté $^{a}$, S.-P. Teh ${ }^{a}$, O. Thinon ${ }^{a}$, H. Provendier ${ }^{\text {a }}$, A.C. Van Veen ${ }^{\text {a }}$, B.J. Beccard ${ }^{\text {b }}$, \\ Y. Schuurman ${ }^{\mathrm{a}, *}$, C. Mirodatos ${ }^{\mathrm{a}}$
}

${ }^{a}$ IRCELYON, Institut de recherches sur la catalyse et l'environnement de Lyon, Université Lyon 1, CNRS, UMR 5256, 2 Avenue Albert Einstein, F-69626 Villeurbanne, France ${ }^{\mathrm{b}}$ Thermo Fisher Scientific, 16 Avenue du Québec, SILIC 765, 91963 Courtaboeuf Cedex, France

\begin{abstract}
A new experimental reactor concept is presented for spatially resolved DRIFTS surface analysis in a microstructured catalytic reactor. Both gas and surface adspecies concentration profiles can be established along the channels coated with a catalyst.

The oxidation of carbon monoxide was studied from 25 to $300{ }^{\circ} \mathrm{C}$ over a $\mathrm{Pt} / \mathrm{Al}_{2} \mathrm{O}_{3}$ and a $\mathrm{Pt} / \mathrm{CeO}_{2}-\mathrm{Al}_{2} \mathrm{O}_{3}$ catalyst. For these operating conditions, nearly isothermal conditions were observed for the microstructured reactor, with a continuous linear increase in the reaction product along the micro-channels. In contrast, an important thermal effect with the characteristic light-off was obtained in a fixed bed DRIFTS reactor, underlining the unique behavior of the microstructured system.

Modeling of the CO conversion and surface adspecies concentration as a function of the temperature along the channels was performed based on a mono-functional reaction mechanism for the case of the alumina-supported catalyst or a bifunctional one taking into account sites on the platinum particles and on the ceria support for the case of the ceria-supported system. The model permits an adequate description of the data along the reactor axis over both catalysts. It underlines the important role of ceria in the creation of an additional site for oxygen chemisorption and the transfer of oxygen to the active site on the Pt/support interface. It also provides new insights in the change of the rate-controlling step from being the oxygen chemisorption on platinum to the $\mathrm{CO}_{2}$ production at the platinum/ceria interface.
\end{abstract}

\section{Introduction}

The ever-increasing environmental concerns and the foreseen decrease in fossil resources force the chemical and petrochemical industry to improve the efficiency of their processes. Thus, the last decade has seen an increased research effort on process intensification $[1,2]$.

Catalytic microstructured reactors offer tremendous potential for process intensification by better control of the reaction conditions and more efficient mass- and heat-transfer thus reducing the energy demand and increasing the selectivity. Many examples of an increase in the catalytic performance in terms of conversion and selectivity in lab-scale microstructures are reported in the literature [3]. Metallic microstructured reactors consist of platelets with several channels with sub millimeter dimensions that make excellent devices for kinetic measurements of fast reactions accompanied with large heat effects [2-5]. This assembly/stacking of microstructured platelets is coated with suitable catalysts. Due to their high heat and mass transfer rates and the low-pressure

\footnotetext{
* Corresponding author. Fax: +33478445399.

E-mail address: yves.schuurman@ircelyon.univ-lyon1.fr (Y. Schuurman).
}

drop, they are particularly adapted to exothermic reactions such as catalytic oxidation reactions. Catalyst washcoating procedures, platelets assembly, and operating conditions have been carefully considered for implementing correctly these new structured reactors [6-8]. However, a major challenge remains to investigate the catalytic process along the micro-channels in view of further modeling and better control of the operating conditions. For that purpose, an access to the effective gas and the surface adspecies concentration profiles is required. Until now, only some attempts have been reported to establish a gas concentration profile by sampling the effluents with a micro-capillary along structured reactors (in general monolith based), completed with a thermal mapping for detecting hot spots along the catalytic bed [9].

The oxidation of carbon monoxide, which represents a key step in the process of hydrogen purification before feeding a Proton Exchange Membrane fuel cell and in automotive pollution control, was chosen as a probe reaction to validate this concept. Two types of Pt-based catalysts known to be active for this reaction were selected, $\mathrm{Pt} / \mathrm{Al}_{2} \mathrm{O}_{3}$ and $\mathrm{Pt} / \mathrm{CeO}_{2}-\mathrm{Al}_{2} \mathrm{O}_{3}$.

The objectives of the paper are twofold. First, to evidence specificities of the microstructured spectroscopy cell, the related results were compared to those obtained in a conventional fixed 
bed DRIFTS reactor with similar catalysts in powder form and under similar operating conditions. Secondly, to clearly establish the bifunctional reaction path over $\mathrm{Pt} / \mathrm{CeO}_{2}-\mathrm{Al}_{2} \mathrm{O}_{3}$, it has been compared to a $\mathrm{Pt} / \mathrm{Al}_{2} \mathrm{O}_{3}$ catalyst [10]. Modeling of the data presented here demonstrates the concept of an in situ kinetic spectroscopy cell.

\section{Experimental methods}

\subsection{DRIFTS reactors}

\subsubsection{Optically accessible DRIFTS microstructured reactor}

Fig. 1 shows a schematic design of the optically accessible microstructured reactor as well as a photograph of the outside housing containing the IR window. The catalyst is coated as a thin layer onto a microstructured metal platelet that is located inside the housing right underneath the window. The structured platelet used in this study was made of Aluchrom ${ }^{\circledR}$ (Iron-chromium-aluminum resistance alloy). It is $10 \mathrm{~mm}$ wide, $29 \mathrm{~mm}$ in length, and it contains eight channels with dimensions of $L \times W \times D$ equal to $29 \times 0.5 \times 0.5 \mathrm{~mm}$. This platelet is placed into a reactor housing mounted on a $x y$ table of an infrared optical microscope "Nicolet Continuum" linked to an infrared spectrometer "Nicolet Nexus" equipped with a MCT detector [11]. The microstructured reactor is connected to a gas supply consisting of mass flow controllers. The exit gas is fed to an on-line analysis set-up. This consists of a micro gas chromatograph (Agilent 3000) equipped with a channel module used for $\mathrm{H}_{2}, \mathrm{O}_{2}, \mathrm{~N}_{2}, \mathrm{CH}_{4}$, and $\mathrm{CO}$ measurements (MolSieve 5A, BF PPU Plot, with Ar as carrier gas) and a channel for $\mathrm{CO}_{2}$ and $\mathrm{H}_{2} \mathrm{O}$ (PPU, BF PPQ, with He as carrier gas). The reactor housing can be heated up to $300^{\circ} \mathrm{C}$ by electrical cartridges. Its design allows a laminar flow well distributed among the parallel channels, as demonstrated by computational fluid dynamics calculations performed in our laboratory [6]. The $\mathrm{CaF}_{2}$ window is directly in contact with the platelet, avoiding significant by-pass between the channels. By moving automatically the reactor under the infrared beam, the spatially resolved DRIFTS analysis is carried out along the reactor channels under reaction conditions. During catalytic testing for mapping gas and adspecies concentrations along the microstructured channel, the operating conditions (flow rates and temperature) were maintained constant and the microstructured reactor displaced regularly by means of the $x y$ motorized table under the IR beam till the whole channel was investigated (six analyses per channel). The gas inlet composition was fixed at $\mathrm{CO}: \mathrm{O}_{2}: \mathrm{He}=50 \%: 25 \%: 25 \%$. A flow rate of $50 \mathrm{Nml} / \mathrm{min}$ was used. This high concentration of reacting species was chosen to maximize the DRIFTS signals due to the short optical length. Actually, for this reactor, the optical length of the IR beam within the reacting zone, i.e., the geometrical distance between the reactor window and the catalyst adlayer, was evaluated to be about $0.5 \mathrm{~mm}$ (see Fig. 1). The IR signal was collected according to the $\log (1 / R)$ transform, using a background spectrum acquired by focusing on a catalyst-free zone of the micro-reactor to account for all internal and external non-catalytic contributions. Though a minor specular reflection contribution could not be discarded, it was assumed that the signal was formed essentially from diffuse reflectance as no typical band distortion (a "derivative" signal; Restrahlen) due to specular reflection has been observed in the spectra. In general, the specular reflection decreases, for a given material (constant refractive index), with the particle size [12]. The coatings in the microstructured reactor are obtained from slurry's containing three micron size particles, much smaller than the 50-100 micron particles used in the conventional DRIFT cell. From data collected in classical IR gas cells, it has been estimated that the optical length in the new microstructured IR cell allows detecting correctly a minimum gas phase concentration of $\mathrm{CO}_{2}$ in the range of $3-5 \mathrm{vol} \%$. Therefore, in this study, rather high gas phase concentrations have been used. On the other hand, the small optical length avoids interference of gas phase IR bands and surface species IR bands. It is thus possible to work under undiluted, e.g., industrial, conditions.

Although spectra presented by the Kubelka-Munk transform allow better quantification, this has not been used here due to the too high catalyst concentrations used in order to study the lightoff. In fact, the sample should be highly diluted in a IR transparent material to apply this transform method.
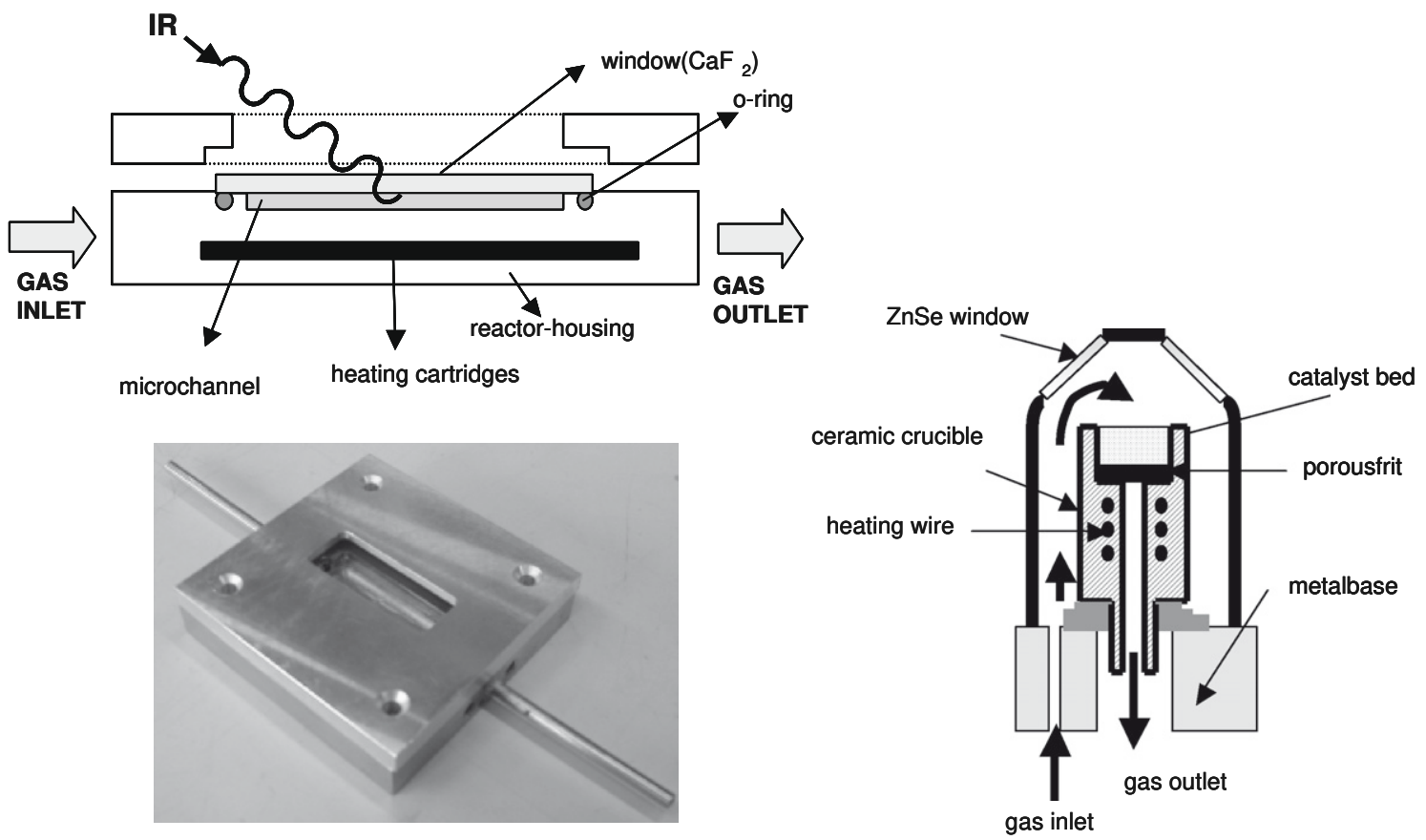

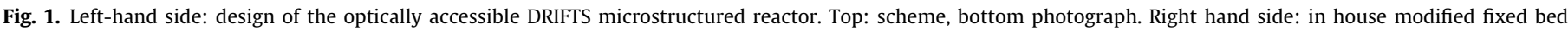
Spectratech ${ }^{\circledR}$ IR reactor. Note that the by-pass has been plugged to force all the gas to pass through the catalyst bed. 


\subsubsection{Fixed bed DRIFTS reactor}

To compare the behavior of a microstructured reactor with a fixed bed one, the DRIFTS analysis was also carried out over a powder sample in an in situ DRIFTS cell from Spectratech [13] (Fig. 1). In previous studies, the CO conversion did not exceed $18 \%$ due to bypassing of the catalyst [10]. Therefore, the Spectratech cell has been modified as reported in [14] to eliminate the by-pass and to force the entire gas mixture to flow through the catalyst bed. This cell can therefore be regarded as a fixed bed plug flow reactor. From an optical point of view, this reactor offers an optical length of approximately $10 \mathrm{~mm}$, about 20 times larger than for the microstructured one.

About $20 \mathrm{mg}$ of powder catalyst with a sieved fraction between 200 and $400 \mu \mathrm{m}$ was loaded into the cell on a layer of silicon carbide to improve the thermal exchange within the fixed bed. A CO/O $/ \mathrm{Or}$ mixture was passed over the catalyst at different temperatures. The gas inlet composition was fixed as either $\mathrm{CO}: \mathrm{O}_{2}: \mathrm{Ar}=0.5 \%$ : $0.6 \%: 98.9 \%$, to maximize the absorbance of adsorbed species and minimize the contribution of gas phase reactants and products, or $\mathrm{CO}: \mathrm{O}_{2}: \mathrm{He}=50 \%: 25 \%: 25 \%$ to compare strictly with the conditions selected for the microstructured system. A flow rate of $50 \mathrm{Nml} /$ min was used. During all these operations, the outlet gas concentration was analysed by the on-line micro gas chromatograph. The same mode of spectra acquisition was used as for the microstructured reactor.

\subsection{Catalysts}

The structured platelet used in this study was made of Aluchrom $^{\circledR}$ (Iron-chromium-aluminum resistance alloy), cleaned, and annealed at $1000^{\circ} \mathrm{C}$ before coating. An alumina sublayer was deposited first by slurry coating using an optimized washcoating recipe (using a solution of acrylic acid mixed with a suspension of alumina, acetic acid, and boehmite) [15], followed by drying at room temperature and slow calcination $(1 \mathrm{~K} / \mathrm{min})$ up to $1000^{\circ} \mathrm{C}$. For the $\mathrm{Pt} / \mathrm{CeO}_{2}-\mathrm{Al}_{2} \mathrm{O}_{3}$ catalyst, this alumina washcoat was then impregnated with a solution of $\mathrm{Ce}\left(\mathrm{NO}_{3}\right)_{3}$. The mixed oxide layer was slowly calcined up to $550{ }^{\circ} \mathrm{C}$. About $2 \mathrm{wt}$.\% of platinum was then added by impregnation from a solution of $\mathrm{Pt}\left(\mathrm{NH}_{3}\right)_{4}(\mathrm{OH})_{2}$ followed by a slow calcination $(1 \mathrm{~K} / \mathrm{min})$ up to $550{ }^{\circ} \mathrm{C}$ [16]. In case of the Pt/ $\mathrm{Al}_{2} \mathrm{O}_{3}$ catalyst, only the steps involving the Pt were followed.

The $\mathrm{Pt} / \mathrm{Al}_{2} \mathrm{O}_{3}$ and $\mathrm{Pt} / \mathrm{CeO}_{2}-\mathrm{Al}_{2} \mathrm{O}_{3}$ powder catalysts used in the fixed bed DRIFTS reactor were prepared by a sol-gel method with formulations close to the ones used for the structured micro-reactor [16,17]. The available platinum surface area has been determined by volumetric hydrogen chemisorption on a BelSorp Max (Bel Japan) apparatus. The measurements have been taken at $90 \mathrm{~K}$ in the case of the ceria sample, as outlined in $[3,18]$ and at $303 \mathrm{~K}$ for the alumina sample. In each case, the reversible and irreversible part of the adsorption isotherm has been measured. The dispersions of the two samples amount to $36 \%$ and $42 \%$ for the $\mathrm{Pt} / \mathrm{Al}_{2} \mathrm{O}_{3}$ and $\mathrm{Pt} / \mathrm{CeO}_{2}-\mathrm{Al}_{2} \mathrm{O}_{3}$ catalysts, respectively.

For both DRIFTS reactors (fixed bed and microstructured), the catalysts were reduced under a flow of $50 \% \mathrm{H}_{2}$ in He from room temperature to $270{ }^{\circ} \mathrm{C}$ at $10^{\circ} \mathrm{C} / \mathrm{min}$ and kept $2 \mathrm{~h}$ at $270{ }^{\circ} \mathrm{C}$ before cooling down under He.

\subsection{Modeling}

The CO oxidation reaction over the two Pt catalysts in the microstructured reactor has been modeled by a sequence of elementary steps presented in this paper. The flow through a microchannel is laminar at the conditions used. Due to the small dimensions of the channels, the flow can be considered as plug flow [19] and one-dimensional.
The set of equations to be solved consists of ordinary non-linear first-order differential equations that form an initial value problem coupled to non-linear algebraic equations. The set of differential and algebraic equations (DAE) was numerically integrated using the ODEPACK library [20]. The physical properties that depend on the temperature, pressure, or flow composition are updated after each integration step. All this is implemented in a FORTRAN code.

\section{Results}

\subsection{CO oxidation in the fixed bed DRIFTS reactor}

The main observed IR bands for the two types of catalysts and their assignment are reported in Table 1, based on generally agreed literature data [21-23].

\subsection{1. $\mathrm{Pt} / \mathrm{Al}_{2} \mathrm{O}_{3}$ catalyst}

Fig. 2 shows the spectra obtained during $\mathrm{CO}$ oxidation reaction carried out in the temperature range $20-300{ }^{\circ} \mathrm{C}$ in the fixed bed DRIFT reactor over the $\mathrm{Pt} / \mathrm{Al}_{2} \mathrm{O}_{3}$ catalyst with the following gas inlet concentration: $\mathrm{CO}: \mathrm{O}_{2}: \mathrm{Ar}=0.5 \%: 0.64 \%$ :balance. The band assignments are reported in Table 1.

Two temperature ranges corresponding to two distinct states of the catalytic surface occupancy are identified in the fixed bed DRIFT reactor:

(i) from room temperature to about $150^{\circ} \mathrm{C}$, the band of linearly adsorbed CO at $2069 \mathrm{~cm}^{-1}$ remains rather narrow and stable, as well as the doublet of gaseous CO at 2100$2175 \mathrm{~cm}^{-1}$. Only a slight increase in intensity from $20^{\circ} \mathrm{C}$ until $100^{\circ} \mathrm{C}$ is noted for the latter with a slight decrease at $150{ }^{\circ} \mathrm{C}$. In the range $4000-3000 \mathrm{~cm}^{-1}$, the $\mathrm{OH}$ groups of the alumina surface both acidic and basic are well defined but in the mean time a very broad absorption band at about $3100 \mathrm{~cm}^{-1}$ is observed at room temperature. It tends to vanish as temperature increases to $150^{\circ} \mathrm{C}$. Between 1200 and $1700 \mathrm{~cm}^{-1}$, small bands are observed at $1660,1615,1510$, and $1433 \mathrm{~cm}^{-1}$. The bands at 1660 and $1433 \mathrm{~cm}^{-1}$ tend to vanish as the temperature increases to $150^{\circ} \mathrm{C}$. By considering this pair of bands and the broad band at $3100 \mathrm{~cm}^{-1}$, it may be suggested that adsorbed formic acid molecules are formed on the surface at low temperature and progressively decompose as the temperature increases. Such an assignment is in line with the hypothesis of Trillo and co-workers [21]. Note, however, that formic acid was never detected at a measurable concentration in the outlet gas stream. Other loosely adsorbed species characteristic of an amphoteric surface might also be considered as acid carbonates or formate adspecies which all contain $\mathrm{C}-\mathrm{O}$ vibration bands in the same 1200 and $1700 \mathrm{~cm}^{-1}$ domain. Finally, the doublet at 2360$2330 \mathrm{~cm}^{-1}$, characteristic of gaseous $\mathrm{CO}_{2}$, develops very slowly from $100^{\circ} \mathrm{C}$ on.

(ii) from 200 to $300^{\circ} \mathrm{C}$, the doublet of gaseous $\mathrm{CO}$ and the linearly adsorbed $\mathrm{CO}$ band at $2065 \mathrm{~cm}^{-1}$ are no longer detected, while the gaseous $\mathrm{CO}_{2}$ doublet is now large and stable with temperature. This abrupt change in surface and gas concentration obviously reflects the light-off of the $\mathrm{CO}$ oxidation, leading to the full conversion of $\mathrm{CO}$ into $\mathrm{CO}_{2}$, as confirmed by the gas phase analysis. In the mean time, the alumina $\mathrm{OH}$ bands have disappeared, and a large band slightly above $3000 \mathrm{~cm}^{-1}$ together with two large bands at 1640 and $1510 \mathrm{~cm}^{-1}$ has developed. Such a trend in band evolution could be explained by the reaction of the alumina $\mathrm{OH}$ groups with adsorbed $\mathrm{CO}$ into formate HCOO species, to be further 
Table 1

The main observed IR bands and their assignment.

Gas phase (both catalysts)

Gaseous CO

$2100-2175 \mathrm{~cm}^{-1}$

doublet

Gaseous $\mathrm{CO}_{2}$

$2390-2280 \mathrm{~cm}^{-1}$

doublet

Pt phase (for both catalysts)

Carbonyls on Pt

$2070-2050 \mathrm{~cm}^{-1}$ (slight changes with coverage

Pt

due to dipolar interactions)

$\mathrm{Pt}-\mathrm{C} \equiv \mathrm{O}$

$\mathrm{Pt}$

Oxide phase $\left(\mathrm{Al}_{2} \mathrm{O}_{3}\right)$

Sharp bands: basic and acid hydroxyl groups

$3760,3720,3660$ and $3575 \mathrm{~cm}^{-1}$

$\mathrm{Al}-\mathrm{OH}$

$\mathrm{Al}_{\mathrm{OH}}^{\mathrm{OH}}$

Formic acid

$3100 \mathrm{~cm}^{-1}$ and 1660 and $1433 \mathrm{~cm}^{-1}$

$\mathrm{HCO}-\mathrm{OH}$

Formate and/or acid carbonate

$3000 \mathrm{~cm}^{-1}, 1597,1395 \mathrm{~cm}^{-1}$

$1650,1430,1230 \mathrm{~cm}^{-1}$

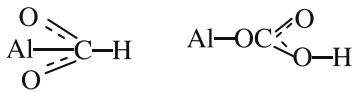

Oxide phase $\left(\mathrm{Al}_{2} \mathrm{O}_{3}-\mathrm{CeO}_{2}\right)$

Type I hydroxyl groups

Type II hydroxyl groups

Unidentate carbonate

Bidentate carbonate

3748 and $3724 \mathrm{~cm}^{-1}$

$3675 \mathrm{~cm}^{-1}$

$1066,1435 \mathrm{~cm}^{-1}$

$1028,1580 \mathrm{~cm}^{-1}$

$\mathrm{Ce}-\mathrm{OH}$

$\mathrm{Ce}-\mathrm{OH}$<smiles>[CH2]OC(=O)O</smiles><smiles>O=C1OCO1</smiles>

$1390,1600 \mathrm{~cm}^{-1}$ $1660,1430,1230 \mathrm{~cm}^{-1}$
${ }_{\mathrm{O}}^{\mathrm{O}} \mathrm{C}^{\mathrm{C}} \mathrm{C}-\mathrm{H}$

$\mathrm{Ce}-\mathrm{OC}=\mathrm{O}-\mathrm{O}$



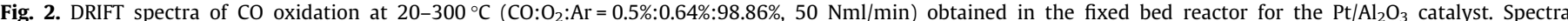
(1400-3800 $\mathrm{cm}^{-1}$ ) corresponding to the temperatures $20,50,100,150,200,250$, and $300{ }^{\circ} \mathrm{C}$ from top to bottom, presented off-set for sake of clarity.

decomposed into gaseous $\mathrm{CO}_{2}$ and/or by direct reaction of $\mathrm{CO}_{2}$ with basic alumina sites to form acid carbonate adspecies HOCOO-Al (generally characterized by a doublet at $1640-1420 \mathrm{~cm}^{-1}$ ). Traces of adsorbed water formed from alumina dehydroxylation cannot be discarded $\left(1640 \mathrm{~cm}^{-1}\right)$.

\subsection{2. $\mathrm{Pt} / \mathrm{CeO} \mathrm{O}_{2}-\mathrm{Al}_{2} \mathrm{O}_{3}$ catalyst}

Fig. 3 shows spectra obtained during $\mathrm{CO}$ oxidation reaction carried out in the fixed bed DRIFT reactor over the $\mathrm{Pt} / \mathrm{CeO}_{2}-\mathrm{Al}_{2} \mathrm{O}_{3}$ cat- alyst under the same operating conditions as for the $\mathrm{Pt} / \mathrm{Al}_{2} \mathrm{O}_{3}$ system.

Concerning the detected adspecies (Table 1 and Fig. 3), the same bands were observed on the Pt phase, i.e., linear carbonyls slightly varying from $2071 \mathrm{~cm}^{-1}$ at $20{ }^{\circ} \mathrm{C}$ to $2050 \mathrm{~cm}^{-1}$ at temperature above $150^{\circ} \mathrm{C}$, as expected from the CO coverage that is decreasing with temperature. In addition, some bands typical of adsorption on the ceria phase were observed (i) in the hydroxyl band domain (3748, 3724 and $3675 \mathrm{~cm}^{-1}$ ) and (ii) in the formate, carbonate, 

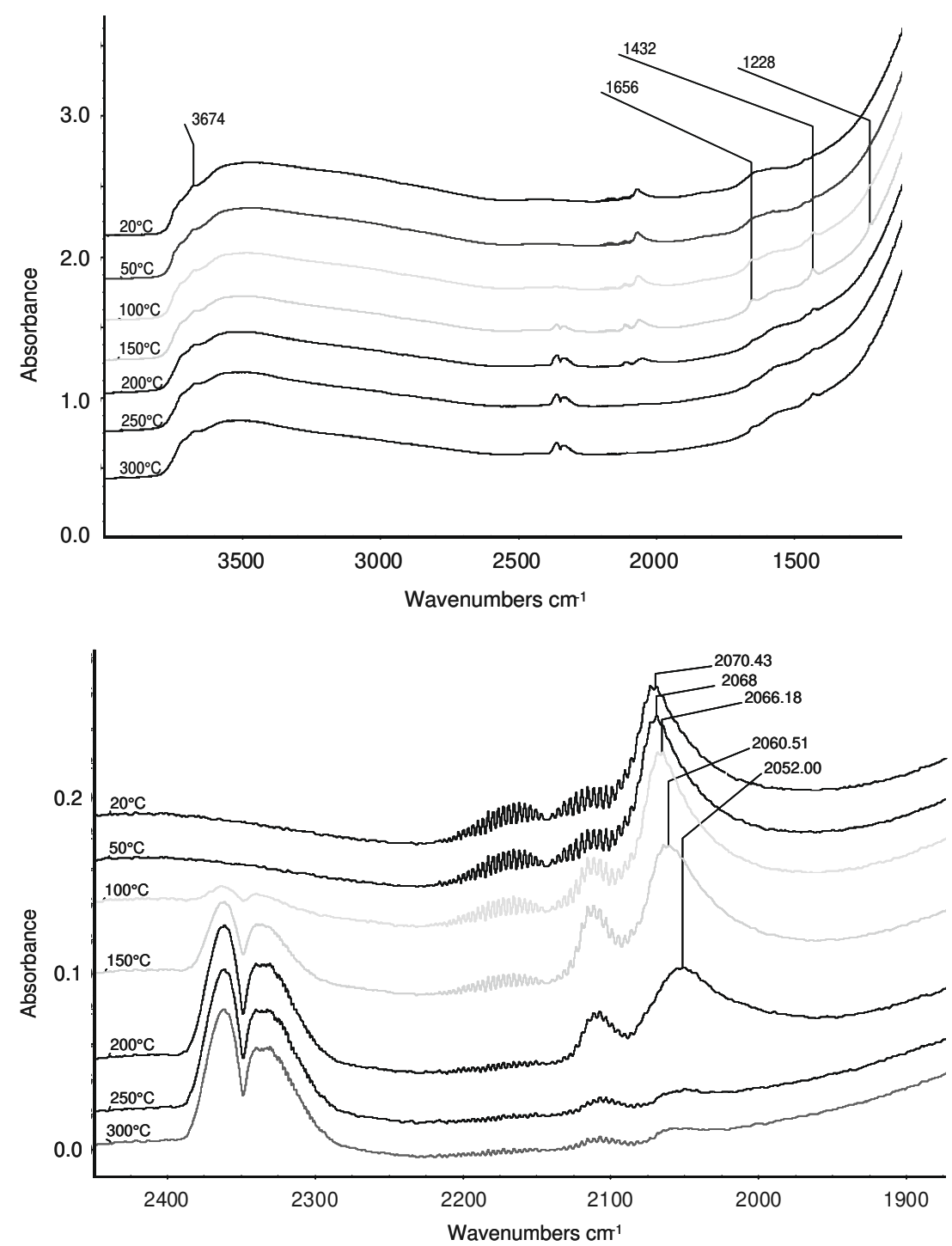

Fig. 3. DRIFT spectra of $\mathrm{CO}$ oxidation at $20-300{ }^{\circ} \mathrm{C}\left(\mathrm{CO}: \mathrm{O}_{2}: \mathrm{Ar}=0.5 \%: 0.64 \%: 98.86 \%, 50 \mathrm{Nml} / \mathrm{min}\right)$ obtained in the fixed bed reactor for the $\mathrm{Pt} / \mathrm{Al}_{2} \mathrm{O}_{3} / \mathrm{CeO}_{2}$ catalyst. For clarity reasons, the spectra have been cut into two parts.

and acid carbonate domain $\left(1390,1600 \mathrm{~cm}^{-1}\right.$, and 1660,1430 , $1230 \mathrm{~cm}^{-1}$, respectively).

Concerning the changes in band intensity with reaction temperature, two temperature domains could be distinguished like for the alumina-supported system, corresponding to two distinct states of the catalytic surface. At low temperatures (below $190^{\circ} \mathrm{C}$ ), the linearly adsorbed $\mathrm{CO}$ band dominates the spectra, while at high temperatures (above $190^{\circ} \mathrm{C}$ ), the gaseous $\mathrm{CO}_{2}$ doublet develops while the adsorbed carbonyls disappear. In addition, the bands typical of ceria adspecies (formates and carbonates) were observed essentially in the low temperature domain just before the fast increase in the CO conversion and their intensity strongly decreased in the high temperature domain, i.e., at high $\mathrm{CO}$ conversion suggesting their direct involvement in the catalytic process.

To compare the two catalytic systems, Fig. 4 shows the changes in (i) CO conversion (measured by on-line GC) and (ii) IR bands integrated surface for gas phase $\mathrm{CO}_{2}$ doublet at $2360-2330 \mathrm{~cm}^{-1}$ and for linear carbonyl adspecies (LCO) at $2069 \mathrm{~cm}^{-1}$ for the Pt/ $\mathrm{Al}_{2} \mathrm{O}_{3}$ and $\mathrm{Pt} / \mathrm{CeO}_{2}-\mathrm{Al}_{2} \mathrm{O}_{3}$ powder catalysts in the fixed bed DRIFTS reactor, when ramping up the temperature of the reactor oven with the following gas inlet concentration: $\mathrm{CO}: \mathrm{O}_{2}: \mathrm{He}=50: 25: 25$.
At $200{ }^{\circ} \mathrm{C}$ in the case of $\mathrm{Pt} / \mathrm{Al}_{2} \mathrm{O}_{3}$ and at $140^{\circ} \mathrm{C}$ in the case of $\mathrm{Pt} /$ $\mathrm{CeO}_{2}-\mathrm{Al}_{2} \mathrm{O}_{3}$, the conversion of $\mathrm{CO}$ jumps from very low levels to a conversion of more than $80 \%$. By ramping down the temperature of the reactor, a marked hysteresis is observed for both cases as the CO conversion remains at high levels at temperatures well below the respective light-off temperatures. Thus, in the case of $\mathrm{Pt} /$ $\mathrm{CeO}_{2}-\mathrm{Al}_{2} \mathrm{O}_{3}$ sample, when the DRIFT reactor furnace is no longer powered, the temperature of the catalyst bed remains around $120^{\circ} \mathrm{C}$ and the conversion close to $80 \%$.

As seen in Fig. 4, the gas phase concentration of carbon dioxide follows strictly the CO conversion profiles while the linear carbonyls concentration varies in the opposite way. The difference in L$\mathrm{CO}$ band intensity between the two samples cannot be straightforwardly related to surface concentration, since the beds height and packing, and therefore, the IR yields were not strictly identical.

\subsection{CO oxidation in the microstructured DRIFTS reactor}

Fig. 5 shows a scanning electron micrograph exposing a part of the microstructured channels. Some cracks in the washcoat at regular intervals are visible but it adheres well and it is stable during 

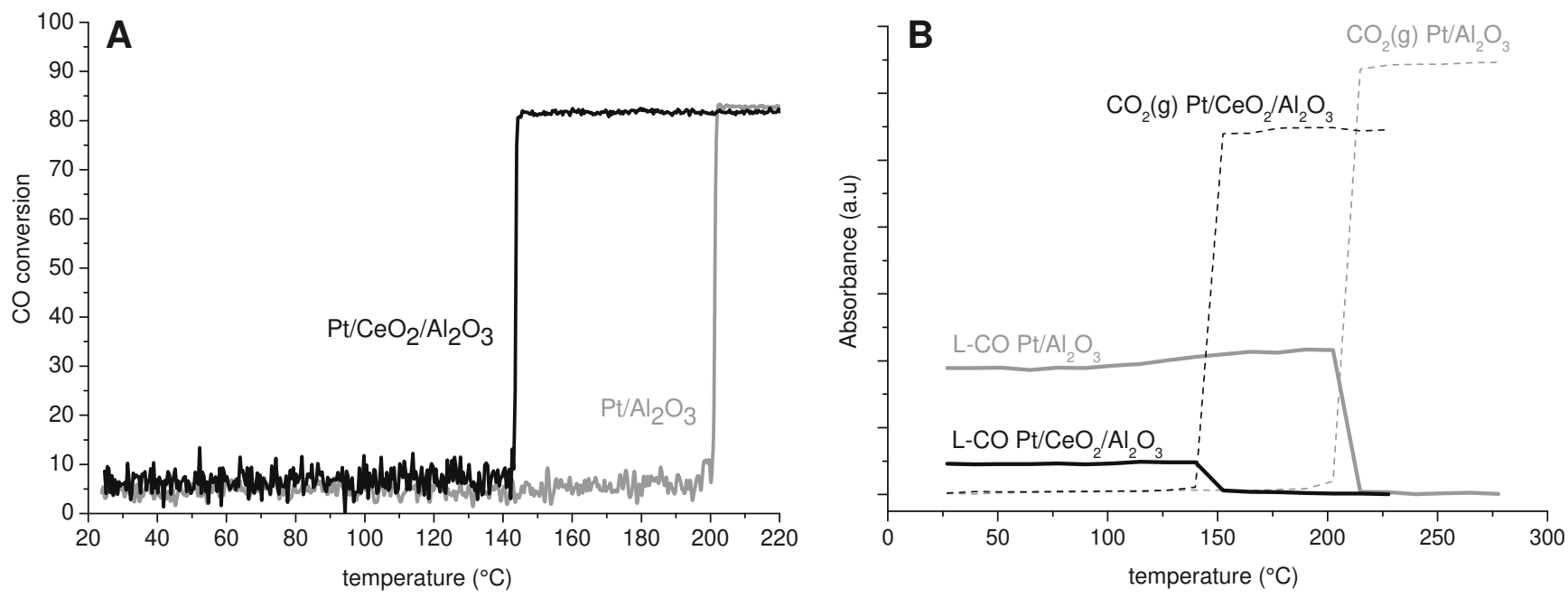

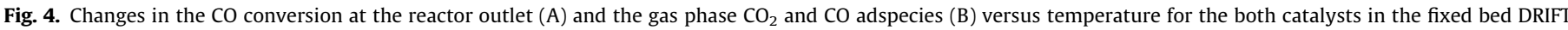
reactor. $\mathrm{CO}: \mathrm{O}_{2}: \mathrm{He}=50 \% / 25 \% / 25 \%, 50 \mathrm{Nml} / \mathrm{min}$.

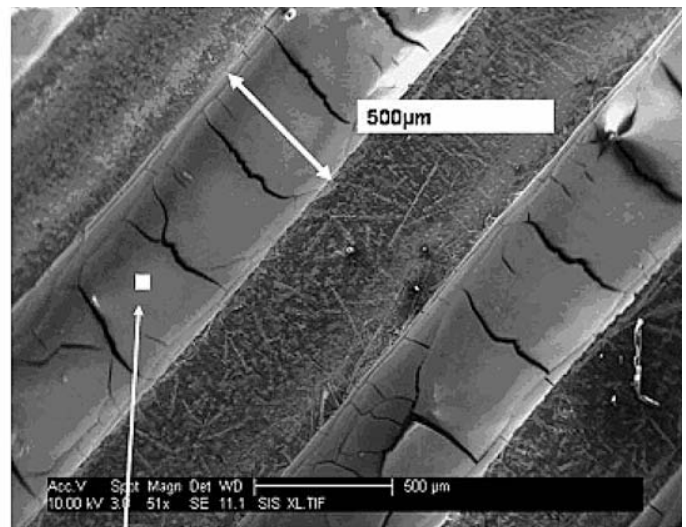

IR beam mask: $50 \mu \mathrm{m} \times 50 \mu \mathrm{m}$

Fig. 5. SEM picture of the coated microplatelet with the size of the beam mask for local DRIFT analysis.

catalytic tests. A square showing the size of the IR beam has been added to the picture to show that the IR analysis domain is very small compared to the channel width. Note that all surface analyses were done by avoiding any surface macro-defects (cracks).

The DRIFTS mapping along the central micro-channel (every $6 \mathrm{~mm}$ ) under reacting conditions at $300{ }^{\circ} \mathrm{C}$ in the case of the Pt/ $\mathrm{CeO}_{2}-\mathrm{Al}_{2} \mathrm{O}_{3}$ catalyst has been reported previously [10]. Due to the small optical length in the microstructure and the high IR spectra acquisition rate, only the most pronounced bands that were observed in the fixed bed reactor were observed in the microstructured DRIFT reactor: (i) linear platinum carbonyls at $2060-2070 \mathrm{~cm}^{-1}$, (ii) gaseous $\mathrm{CO}$ and $\mathrm{CO}_{2}$ at $2100-2200$ and $2300-2400 \mathrm{~cm}^{-1}$, respectively, and (iii) adsorbed formates/carbonates within the $1200-1800 \mathrm{~cm}^{-1}$ range. Only a selected set of bands will be quantified for further modeling.

Fig. 6 reports the changes in the gaseous $\mathrm{CO}_{2}$ IR band intensity along the microstructured reactor axis for the $\mathrm{Pt} / \mathrm{Al}_{2} \mathrm{O}_{3}$ and $\mathrm{Pt} /$ $\mathrm{CeO}_{2}-\mathrm{Al}_{2} \mathrm{O}_{3}$ catalysts. As the IR spectrometer has not been calibrated for gaseous $\mathrm{CO}_{2}$ concentrations, the highest observed IR $\mathrm{CO}_{2}$ signal (at $300^{\circ} \mathrm{C}$ over Pt/CeO $\mathrm{C}_{2}-\mathrm{Al}_{2} \mathrm{O}_{3}$ ) has been set to 1 . Quasi-linear increases in $\mathrm{CO}_{2}$ concentration are observed for both catalysts, the slopes increasing with the reaction temperature, as expected for an activated process. However, it can be seen that

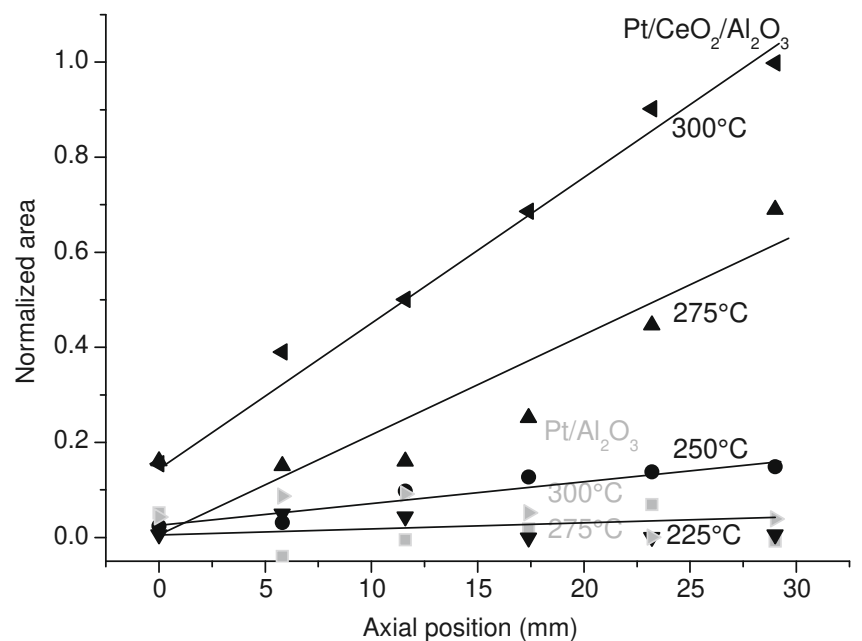

Fig. 6. Changes in the normalized $\mathrm{CO}_{2}$ concentration (doublet at $2360-2330 \mathrm{~cm}^{-1}$ ) along the microstructured channels at various temperatures for both $\mathrm{Pt} / \mathrm{Al}_{2} \mathrm{O}_{3}$ and $\mathrm{Pt} / \mathrm{CeO}_{2}-\mathrm{Al}_{2} \mathrm{O}_{3}$ catalysts. The lines are only a guide to the eye.

about 10 times more carbon dioxide is formed with the $\mathrm{Pt} / \mathrm{CeO}_{2}-$ $\mathrm{Al}_{2} \mathrm{O}_{3}$ catalyst than with the $\mathrm{Pt} / \mathrm{Al}_{2} \mathrm{O}_{3}$ one for similar reaction conditions.

Fig. 7 reports the changes in surface concentration measured for the linear carbonyl species $\left(2084-2053 \mathrm{~cm}^{-1}\right)$ along the reactor axis for the $\mathrm{Pt} / \mathrm{CeO}_{2}-\mathrm{Al}_{2} \mathrm{O}_{3}$ catalysts. In contrast with the previous linear increases in $\mathrm{CO}_{2}$ gas concentration along the micro-channels, no significant changes are observed within the uncertainty of the spectrum acquisition. The rather large scattering of the data is mainly due to the weak IR signal resulting from the limited amount of reflecting material. Some changes in the coating thickness along the axial micro-channels might also contribute to this data scattering. Even by lumping the formates and carbonates adspecies together within the range of $1660-1550 \mathrm{~cm}^{-1}$, the scattering was very large but the concentration did not change significantly with the axial position (not shown). No calibration of the IR spectrometer for the linear carbonyl species was performed. In order to compare the experimental IR data with the model, it was assumed that at the lowest temperature $\left(200^{\circ} \mathrm{C}\right)$, the surface coverage of the linear carbonyl species is equal to 1.0 , as suggested by the work of 


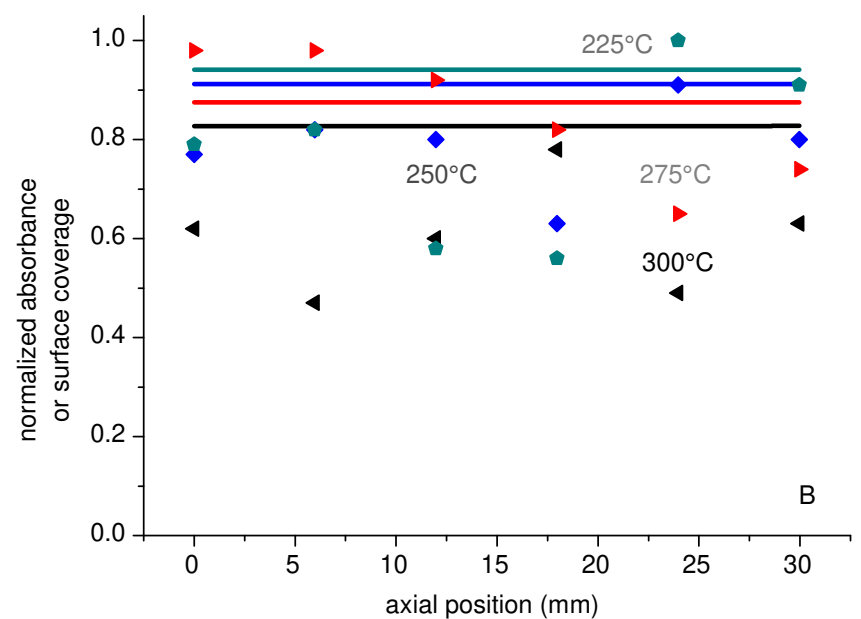

Fig. 7. Changes in linear carbonyl on platinum $\left(2084-2053 \mathrm{~cm}^{-1}\right)$ along the microstructured channels between 225 and $300{ }^{\circ} \mathrm{C}$ for the $\mathrm{Pt} / \mathrm{CeO}_{2}-\mathrm{Al}_{2} \mathrm{O}_{3}$ catalyst. The lines are the $\mathrm{CO}$ coverage calculated according to the model presented in Table

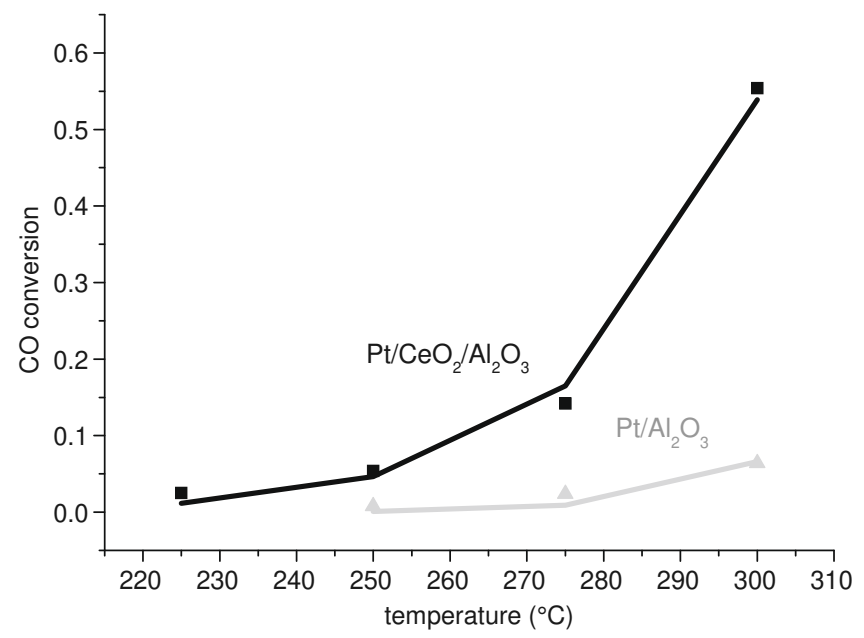

Fig. 8. Changes in $\mathrm{CO}$ conversion with temperature at the outlet of the DRIFTS microstructured reactor for the $\mathrm{Pt} / \mathrm{Al}_{2} \mathrm{O}_{3}$ and $\mathrm{Pt} / \mathrm{CeO}_{2}-\mathrm{Al}_{2} \mathrm{O}_{3}$ catalysts. Micro-GC data (symbols) and model corresponding to Table 2 (full lines).

Bourane and Bianchi [24]. It can therefore be concluded at this stage that the coverage of the catalyst all along the channels was not varying in a significant way within the $225-300{ }^{\circ} \mathrm{C}$ temperature range.

Fig. 8 reports the changes in the CO conversion with the temperature as measured at the outlet of the DRIFTS microstructured reactor over both catalysts. No light-off effects (i.e., abrupt change in the conversion) nor hysteresis effect when ramping down the temperature were observed with the microstructured reactor, contrary to the CO conversion curves obtained with the fixed bed DRIFTS reactor (see Fig. 4). Similar CO conversion levels were observed by either ramping the temperature up or down. It can be noted in addition that a much higher $\mathrm{CO}$ conversion is observed (about one order of magnitude) for the $\mathrm{Pt} / \mathrm{CeO}_{2}-\mathrm{Al}_{2} \mathrm{O}_{3}$ catalyst when compared to the $\mathrm{Pt} / \mathrm{Al}_{2} \mathrm{O}_{3}$ catalyst, over the whole the temperature range.

\section{Discussion}

Three key features were gained from the experimental results and deserve to be discussed: (i) the marked difference in the ki- netic effects between the two DRIFT reactors, (ii) the marked difference in catalytic efficiency between the two types of tested catalysts, and (iii) the spatially resolved catalytic data obtained in the microstructured system (concentration profiles) that can be used for reactor modeling and process optimization.

\subsection{Comparison between the fixed bed and microstructured DRIFTS reactors}

\subsubsection{Fixed bed reactor}

Reaction light-off and run-away (abrupt increase from low to full CO conversion) were observed only in the fixed bed DRIFTS reactor (Fig. 4A and B). This is generally ascribed to the differences between temperatures at the catalytic surface and the gas phase due to significant heat transfer resistances. It leads to the full conversion of the linear carbonyl adspecies on the Pt particles, with the simultaneous disappearance of the gas phase $\mathrm{CO}$ and the abrupt increase in the gaseous $\mathrm{CO}_{2}$ (Fig. $4 \mathrm{C}$ and $\mathrm{D}$ ). The two temperature domains observed experimentally in the fixed bed DRIFTS reactor correspond respectively to two distinct states of the active surface: (i) below $200{ }^{\circ} \mathrm{C}$ in the case of $\mathrm{Pt} / \mathrm{Al}_{2} \mathrm{O}_{3}$ and below $140{ }^{\circ} \mathrm{C}$ in the case of $\mathrm{Pt} / \mathrm{CeO}_{2}-\mathrm{Al}_{2} \mathrm{O}_{3}$, a full coverage of Pt particles by linear carbonyls strongly inhibits the oxygen activation and therefore keeps the CO conversion at a low level and (ii) above these two threshold temperatures, a drastic change in Pt particles coverage occurs and the Pt particles are now mainly covered with activated oxygen, immediately reacting with $\mathrm{CO}$ as soon as they collide with the Pt surface. The strong hysteresis effect when ramping down the temperature is in line with quasi autothermal behavior after reaction light-off, where the heat produced by the fast combustion of CO compensates the heat losses by convection and radiation.

\subsubsection{Microstructured reactor}

In contrast with the fixed bed reactor, over the whole $25-300{ }^{\circ} \mathrm{C}$ temperature range, the microstructured reactor leads to a monotonous change in $\mathrm{CO}$ conversion with temperature (Fig. 8). This demonstrates the excellent heat transfer in this microstructured system, which prevents any run-away of the CO oxidation, confirming this unique property of microstructured reactors $[3,4]$. Accordingly, as demonstrated by the DRIFTS analysis carried out in the microstructured reactor (Fig. 8B), the coverage of the platinum particles by linear carbonyls remains high over the whole range of the explored reacting conditions only decreasing slightly between room temperature and $300{ }^{\circ} \mathrm{C}$. This quasi isothermal behavior of the microstructured system will be demonstrated later by its modeling, showing that this reactor is quite suitable for acquiring kinetic data in an isothermal regime.

\subsection{Comparison of $\mathrm{Pt} / \mathrm{Al}_{2} \mathrm{O}_{3}$ and $\mathrm{Pt} / \mathrm{CeO}_{2}-\mathrm{Al}_{2} \mathrm{O}_{3}$ catalysts}

As shown in Fig. 4A and $\mathrm{B}$, the light-off temperature in the fixed bed flow reactor was about $60{ }^{\circ} \mathrm{C}$ lower for the $\mathrm{Pt} / \mathrm{CeO}_{2}-\mathrm{Al}_{2} \mathrm{O}_{3}$ than for the $\mathrm{Pt} / \mathrm{Al}_{2} \mathrm{O}_{3}$ catalyst $\left(140^{\circ} \mathrm{C}\right.$ and $200{ }^{\circ} \mathrm{C}$, respectively). In the case of the microstructured reactor, which allows a quantitative comparison of the conversion levels along the channels, the $\mathrm{CO}_{2}$ concentration is about ten times higher over the ceria-supported catalyst than for the alumina-only supported catalyst (Fig. 6), that ratio being reflected by the change in $\mathrm{CO}$ conversion with temperature at the reactor outlet as reported in Fig. 8. Thus, the ceria-alumina-based system is approximately one order of magnitude more active than the alumina-based one. This result agrees with data reported in the literature $[25,26]$ indicating an enhancement factor from 5 to 10 after ceria promotion of alumina-supported Pt catalysts for CO oxidation in a conventional fixed bed reactor.

The specific role of ceria can be described as an oxygen provider toward Pt particles, ensuring a large and continuous flow of 
activated oxygen at the Pt/support interface. In contrast, with the $\mathrm{Pt} / \mathrm{Al}_{2} \mathrm{O}_{3}$, the main source for activated oxygen is provided by the direct reaction of gaseous oxygen on the Pt particles. The oxidizing role of the support might also involve surface hydroxyl groups, well identified at low temperature for both systems. They might promote at $\mathrm{Pt} /$ support interface the oxidation of $\mathrm{CO}$ carbonyls via the transient formate/carbonate intermediates. The surface mobility of these hydroxyl groups and their reactivity with adsorbed carbonyls was demonstrated to be much more favored on ceria-based systems, likely due to high surface concentration in defects $[27,28]$. Note that the proper intrinsic activity of the supports (ceria/alumina and alumina) has been found negligible from specific experiments not reported here.

The oxygen activation and transfer capability of ceria-supported systems have been demonstrated for many reactions, especially under transient conditions [29,30], and the role of surface and bulk oxygen vacancies, the former favoring the high surface mobility, has been clearly evidenced $[31,32]$. In other words, the ceria-supported catalyst can be considered as bifunctional, while the alumina-supported one behaves essentially as mono-functional.

\subsection{Modeling of $\mathrm{CO}$ oxidation}

CO oxidation over Pt-based catalysts has been studied extensively over a wide range of conditions [33-35]. A large number of mechanisms have been proposed, with in recent years a preference of Langmuir-Hinshelwood types of mechanisms over the Eley-Rideal approach [36]. However, no real consensus is reached, and many variations are presented that each describes a part of the large experimental data. The variations mainly concern the mode of oxygen adsorption and the oxygen adspecies present on platinum (e.g., molecular versus dissociative oxygen adsorption, exclusion models, compression effects) [36,37].

The aim of this study is not to discriminate between the different models but to underline the role of the support in the oxidation of carbon monoxide. Therefore, a reaction mechanism taking into account reactions on the platinum sites as well as on the ceria for the ceria-supported catalyst will be developed in this section. Ceria has been added to three-way catalysts to improve its thermal stability and to store and supply oxygen during the lean/rich cycles and thus enhances the overall CO oxidation rate [38].

Recently, Mhadeshwar and Vlachos [39] developed a thermodynamically consistent reaction mechanism for CO oxidation over platinum and tested it against a large set of data. They specifically included coverage-dependent sorption enthalpies for oxygen and carbon monoxide. Table 2 gives the reaction steps with the values of the rate parameters used in this study. Steps 1-4 refer to the Pt chemistry for $\mathrm{CO}$ and $\mathrm{O}_{2}$ chemisorption, Langmuir-Hinshelwood surface reaction and $\mathrm{CO}_{2}$ sorption, as proposed by Mhadeshwar and Vlachos [39].
Nibbelke and co-workers $[25,40]$ studied extensively the oxidation of carbon monoxide over both a $\mathrm{Pt} / \mathrm{Al}_{2} \mathrm{O}_{3}$ and over a three-way $\mathrm{PtRh} / \mathrm{CeO}_{2} / \mathrm{Al}_{2} \mathrm{O}_{3}$ catalyst. They established a reaction mechanism for the oxidation of carbon monoxide that involves active sites associated with the platinum particles and ceria. They established a bifunctional reaction path for the ceria-based catalyst along the lines presented in Table 2. Step 5 describes the oxygen activation on the support sites, and step 6 the oxidation of carbonyl species at the metal/support interface. Finally, step (7) concerns desorption of $\mathrm{CO}_{2}$ from ceria, where it is adsorbed most likely in the form of carbonate species.

Only a few parameters that occur in the set of elementary steps can be reliably estimated from the limited available experimental data. Therefore, most of the rate constants for steps 1-4 have been fixed at the values reported by Mhadeshwar and Vlachos [39]. These values are in line with values estimated from collision theory and transition state theory [41] and are thermodynamically consistent. Only the value of the pre-exponential factor for the $\mathrm{CO}$ desorption has been adjusted from its initial value through regression analysis of the experimental data over $\mathrm{Pt} / \mathrm{Al}_{2} \mathrm{O}_{3}$.

The values of the rate parameters for $\mathrm{O}_{2}$ chemisorption on ceria were taken similar as over platinum. In any case, these values could be changed in a large range without affecting the fit of the experimental data. The pre-exponential factor and the activation energy for the forward step (6) have been obtained through regression analysis of the experimental data over $\mathrm{Pt} / \mathrm{CeO}_{2}$. The rate parameters for the back reaction (6) are calculated based on thermodynamic data along the lines described in Ref. [42]. The values of the rate parameters from step (7) have been estimated from TPD experiments of $\mathrm{CO}_{2}$ over ceria [43].

The model that includes only the platinum sites (steps 1-4) describes the data over the $\mathrm{Pt} / \mathrm{Al}_{2} \mathrm{O}_{3}$ very well with the parameter values listed in Table 2, as shown in Fig. 8, representing the CO conversion as a function of temperature. As stated earlier, only the value of one parameter has been changed to obtain the fit of the experimental data. This indicates that the alumina-supported $\mathrm{Pt}$ catalyst compares well with unsupported Pt, which was used to optimize the original parameter set. The conditions used in this study indicate that the surface coverage of carbon monoxide is very high and that of oxygen very low.

As discussed previously, the specificity of ceria promoted $\mathrm{Pt} /$ $\mathrm{CeO}_{2} / \mathrm{Al}_{2} \mathrm{O}_{3}$ is to offer a second route for oxygen activation over the ceria surface in parallel to the main route of oxygen activation on the Pt phase. It is formalized by adding the elementary steps (5)-(7) to the above-mentioned mechanism restricted to the $\mathrm{Pt}$ phase. A parallel $\mathrm{CO}_{2}$ production takes place through the reaction between an adsorbed carbon monoxide species on platinum and surface oxygen species on ceria.

The full reaction sequence presented in Table 2 was considered for calculating the $\mathrm{CO}$ oxidation over the $\mathrm{Pt} / \mathrm{CeO}_{2}-\mathrm{Al}_{2} \mathrm{O}_{3}$. Fig. 8

Table 2

Proposed reaction sequence and kinetic parameters. ${ }^{*}$ Represents a Pt site and s a site on the ceria support.

\begin{tabular}{|c|c|c|c|c|c|}
\hline \multirow[t]{2}{*}{ Step } & & \multicolumn{2}{|l|}{ Forward } & \multicolumn{2}{|l|}{ Backward } \\
\hline & & $s^{0}$ or $k\left(\mathrm{~s}^{-1}\right)$ & $E_{a}\left(\mathrm{~kJ} \mathrm{~mol}^{-1}\right)$ & $s^{0}$ or $k\left(\mathrm{~s}^{-1}\right)$ & $E_{a}\left(\mathrm{~kJ} \mathrm{~mol}^{-1}\right)$ \\
\hline 1 & $\mathrm{CO}_{\mathrm{g}}+^{*} \rightleftharpoons \mathrm{CO}^{*}$ & 1.0 & 0 & $5.8 \pm 0.6^{\mathrm{a}} \times 10^{14}$ & $167.4-62.8 \theta_{\mathrm{CO}}$ \\
\hline 2 & $\mathrm{O}_{2, \mathrm{~g}}+{ }^{*} \rightleftharpoons 2 \mathrm{O}^{*}$ & 0.05 & 0 & $8.4 \times 10^{12}$ & $212.9-133.9 \theta_{\mathrm{O}}$ \\
\hline 3 & $\mathrm{CO}^{*}+\mathrm{O}^{*} \rightleftharpoons \mathrm{CO}_{2}^{*}+{ }^{*}$ & $2.4 \times 10^{11}$ & $86.0-37.4 \theta_{\mathrm{CO}}-18.1 \theta_{\mathrm{O}}$ & $3.9 \times 10^{11}$ & $110.2+25.3 \theta_{\mathrm{CO}}+48.8 \theta_{\mathrm{O}}$ \\
\hline 4 & $\mathrm{CO}_{2}^{*} \rightleftharpoons \mathrm{CO}_{2, \mathrm{~g}}+^{*}$ & $2.8 \times 10^{13}$ & 15.1 & 0.2 & 0.0 \\
\hline 5 & $\mathrm{O}_{2, \mathrm{~g}}+\mathrm{s} \rightleftharpoons 2 \mathrm{Os}$ & 0.05 & 0 & $1.0 \times 10^{13}$ & 210.0 \\
\hline 6 & $\mathrm{CO}^{*}+\mathrm{Os} \rightleftharpoons \mathrm{CO}_{2} \mathrm{~s}+{ }^{*}$ & $1.0 \pm 0.5^{\mathrm{a}} \times 10^{13}$ & $156.6 \pm 3^{\mathrm{a}}-37.4 \theta_{\mathrm{CO}}$ & $6.3 \times 10^{11}$ & $261.0+25.3 \theta_{\mathrm{CO}}$ \\
\hline \multirow[t]{2}{*}{7} & $\mathrm{CO}_{2} \mathrm{~s} \rightleftharpoons \mathrm{CO}_{2, \mathrm{~g}}+\mathrm{s}$ & $1.0 \times 10^{13}$ & 67.0 & 1.0 & 0.0 \\
\hline & $\mathrm{CO}_{\mathrm{g}}+1 / 2 \mathrm{O}_{2, \mathrm{~g}} \rightleftharpoons \mathrm{CO}_{2, \mathrm{~g}}$ & $\Delta S_{\left(250{ }^{\circ} \mathrm{C}\right)}^{0}=-88.6 \mathrm{~J} / \mathrm{K} \mathrm{mol}$ & $\Delta H_{\left(250^{\circ} \mathrm{C}\right)}=-283.8 \mathrm{~kJ} / \mathrm{mol}$ & & \\
\hline
\end{tabular}

\footnotetext{
${ }^{\text {a }}$ Estimated through regression analysis of the data shown in Fig. 9. The estimated values are shown \pm the $95 \%$ confidence intervals.
} 


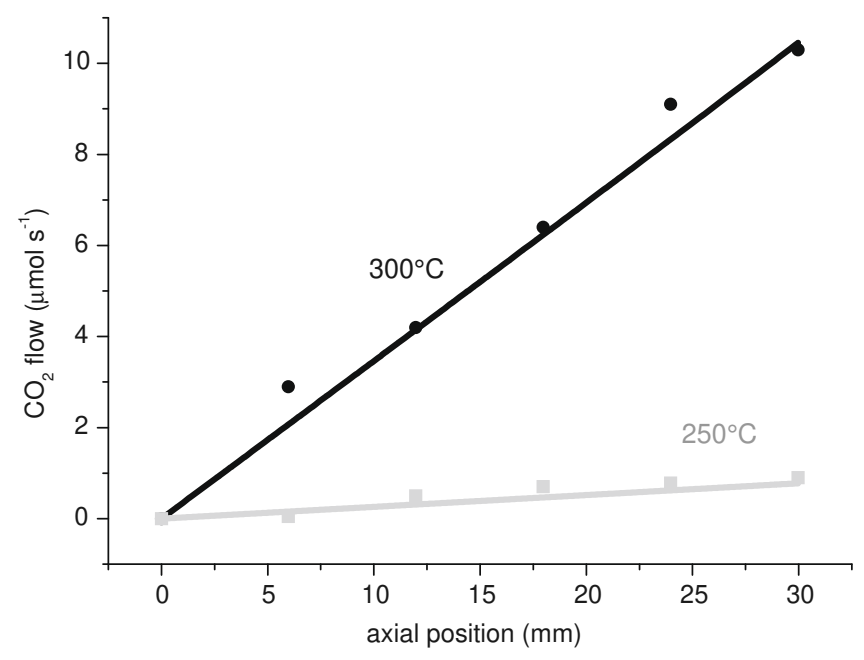

Fig. 9. Experimental (symbols) and calculated (lines), using the model presented in Table 2, $\mathrm{CO}_{2}$ concentration (expressed as a local flowrate) profiles along a microchannel at 250 and $300{ }^{\circ} \mathrm{C}$ over the $\mathrm{Pt} / \mathrm{CeO}_{2}-\mathrm{Al}_{2} \mathrm{O}_{3}$ catalyst.

shows the good comparison of the calculated and experimental data for the $\mathrm{CO}$ conversion over the $\mathrm{Pt} / \mathrm{CeO}_{2}-\mathrm{Al}_{2} \mathrm{O}_{3}$ at the reactor outlet as a function of the temperature. In Fig. 9, some of the experimental IR data taken from Fig. 6 represent the $\mathrm{CO}_{2}$ flow as a function of the axial position at two different temperatures. As can be seen, the adequacy of the model is confirmed for these axial profiles, by the good correspondence between calculated (line) and the experimental IR $\mathrm{CO}_{2}$ bands (symbols). Finally, a comparison between the calculated $\mathrm{CO}$ coverages (line) and those measured experimentally (symbols) in the microstructured reactor by DRIFTS is illustrated in Fig. 7. In order to evaluate the CO coverage from the DRIFTS data, the surface area under the linear CO carbonyls on Pt has been set to a CO coverage equal of 1 at ambient temperature under flowing $\mathrm{CO}$, i.e., assuming in this case surface saturation, as generally agreed in the literature [24]. As can be seen in Fig. 7, the uncertainty of the IR data is rather large, but the model trends fit reasonably well. Both the experimental and the model predicted CO coverage decrease slowly with increasing temperature and along the channel length, although this is nearly invisible for the model. Indeed, no abrupt change in CO coverage is observed in the explored temperature domain, as predicted by the absence of any light-off.

Using Campbell's definition for the degree of rate control, the rate-controlling steps can be established $[44,45]$ :

$X_{r c, i}=\left(\frac{k_{i}}{r}\right)\left(\frac{\delta r}{\delta k_{i}}\right)$

In Eq. (1), where $X_{r c, i}$ is the degree of rate control and $r$ is the overall rate, the partial derivative is taken while keeping constant the equilibrium constant for step $i$ and the rate constants $k_{j}$ for all other steps $j$. This is accomplished by increasing both values of the forward and backward rate constant, $k_{i}$, by $1 \%$. The step whose increase leads to the greatest increase in overall rate or CO conversion is then the most rate-controlling step in the aforementioned sequence $[44,45]$.

In the case of $\mathrm{CO}$ oxidation over $\mathrm{Pt} / \mathrm{Al}_{2} \mathrm{O}_{3}$, the adsorption of oxygen on platinum (step (2) in Table 2 ) is the only rate-controlling step, as the value of $X_{r c, 2}$ equals 1.0 at all temperatures. As the $\mathrm{CO}$ chemisorption is very strong on platinum, the $\mathrm{CO}$ surface coverage is very high (see Fig. 7). Oxygen competes for the same platinum sites as CO and since there are very few free sites available, the oxygen adsorption rate is low. By adding ceria to the catalyst, the most rate-controlling step has been identified as step (6) in
Table 2. $X_{r c, 6}$ amounts to 0.98 , while $X_{r c, 2}$ has dropped to 0.02 . Effectively, ceria provides new sites for oxygen adsorption thereby circumventing the slow oxygen adsorption on platinum and thus enhancing the rate of $\mathrm{CO}$ oxidation that much that now the ratecontrolling step is the $\mathrm{CO}_{2}$ production at the platinum/ceria interface. Nibbelke et al. [25] showed through a reaction path analysis that the bifunctional and mono-functional oxidation routes depend on the partial pressure of oxygen. Under the conditions used in this study, the bifunctional path prevails in agreement with the analysis of the rate-controlling step.

One can note here that the above-mentioned modeling of the CO oxidation along the platelet channels is under isothermal conditions, due to the excellent heat transfer between the catalytic sites and the metallic substrate. Although modeling of light-off phenomena has been carried out [46], it presents a much more complicated process leading to more uncertainty on the kinetic models when compared to intrinsic kinetics obtained in an isothermal reactor.

\section{Conclusions}

This study demonstrates the potential of an original reactor that combines in situ infrared spectroscopy with well-defined hydrodynamic conditions for kinetic studies. The ability to map the surface adspecies and gas concentration by means of the DRIFTS/microscope analysis was used to establish a microkinetic model of the $\mathrm{CO}$ oxidation over $\mathrm{Pt} / \mathrm{Al}_{2} \mathrm{O}_{3}$ and $\mathrm{Pt} / \mathrm{CeO}_{2}-\mathrm{Al}_{2} \mathrm{O}_{3}$ catalysts. This model describes correctly the experimental data corresponding to this mapping for both the gas phase species and the adsorbed species. By comparing the data and the model for both catalysts, the important role of the ceria has been explained. The addition of ceria to a $\mathrm{Pt} / \mathrm{Al}_{2} \mathrm{O}_{3}$ creates an additional site for oxygen chemisorption and changes the rate-controlling step from being the oxygen chemisorption on platinum to the $\mathrm{CO}_{2}$ production at the platinum/ceria interface.

The changes of the $\mathrm{CO}$ conversion with temperature in the microstructured reactor and in a fixed bed DRIFTS reactor over both catalysts showed the excellent heat management of the microstructured reactor (isothermal behavior without heat transfer limitations) whereas the fixed bed reactor showed a strong light-off behavior making it unsuitable for quantitative kinetic studies.

IR spectroscopy in microstructured reactors permits a very small optical path due to the small channel dimensions thus reducing the gas phase contribution in the IR spectrum. This will allow for a number of reactions the use more realistic feeds using higher partial pressures of reactants. However, the IR signals of the surface species in this study were rather low most probably due to the low reflectance of the surface coating. Further optimization of this coating is necessary to obtain the full potential offered by this IR mapping approach.

\section{References}

[1] M.V. Koch, K.M. VandenBussche, R.W. Chrisman (Eds.), Micro Instrumentation: for High Throughput Experimentation and Process Intensification, Wiley-VCH, Weinheim, 2007.

[2] F. Dautzenberg, M. Mukherjee, Chem. Eng. Sci. 56 (2001) 251.

[3] W. Ehrfeld, V. Hessel, H. Loewe, Microreactors, Wiley-VCH, Weinheim, 2000.

[4] G. Germani, Y. Schuurman, AIChE Journal 52 (2006) 1806.

[5] N. Dupont, G. Germani, A.C. van Veen, Y. Schuurman, G. Schäfer, C. Mirodatos, Int. J. Hydrogen Energy 32 (2007) 1443.

[6] A.C. Van Veen, Y. Schuurman, C. Mirodatos, Catalyst development, screening, and optimisation in micro process engineering: a comprehensive handbook, vol C, in: V. Hessel, J. Schouten, A. Renken, J.-I. Yoshida (Eds.), System, Process and Plant Engineering, Wiley-VCH, 2009.

[7] R. Zapf, C. Becker-Willinger, K. Berresheim, H. Bolz, H. Gnaser, V. Hessel, G. Kolb, P. Löb, A.-K. Pannwitt, A. Ziogas, Trans. IchemE 81 (2003) 721 
[8] G. Germani, A. Stefanescu, A.C. van Veen, Y. Schuurman, Chem. Eng. Sci. 62 (2007) 5084.

[9] M. Bosco, F. Vogel, Catal. Today 116 (2006) 348.

[10] C. Daniel, M-O. Clarté, H. Provendier, A.C. Van Veen, Y. Schuurman, B.J. Beccard, C. Mirodatos, C.R. Acad. Sci. Paris, Serie IIC Chimie/Chemistry 12 (2009) 647.

[11] <www.Thermoptec.com>.

[12] Ch. Depecker, La réflexion diffuse associée à la spectrometrie IRTF: Une nouvelle étape dans l'analyse in situ des composes solides, University of Lille, France, 1988.

[13] A. Slagtern, Y. Schuurman, C. Leclercq, X. Verykios, C. Mirodatos, J. Catal. 172 (1997) 118.

[14] F.C. Meunier, A. Goguet, S. Shekhtman, D. Rooney, H. Daly, Appl. Catal. 340 (2008) 196.

[15] A. Stefanescu, A.C. van Veen, C. Mirodatos, J.C. Beziat, E. Duval-Brunel, Catal. Today 125 (2007) 16.

[16] S.P. Teh, Ph.D. Thesis, Lyon University, No. 24-2005, 2005.

[17] G. Germani, P. Alphonse, M. Courty, Y. Schuurman, C. Mirodatos, Catal. Today 110 (2005) 114.

[18] V. Perrichon, L. Retailleau, P. Bazin, M. Daturi, JC. Lavalley, Appl. Catal. A. 260 (2004) 1.

[19] Y. Schuurman, Catal. Today 138 (2008) 15.

[20] A.C. Hindmarsh, ODEPACK, A Systematized Collection of ODE Solvers, in Scientific Computing, in: R.S. Stepleman et al. (Eds.), IMACS Transactions on Scientific Computation, vol. 1, North-Holland, Amsterdam, 1983, p. 55.

[21] J.M. Trillo, G. Munuera, J.M. Criado, Catal. Rev. 7 (1972) 51.

[22] D.G. Rethwisch, J.A. Dumesic, Langmuir 2 (1986) 73.

[23] C. Binet, M. Daturi, J-C. Lavalley, Catal. Today 50 (1999) 207.

[24] A. Bourane, D. Bianchi, J. Catal. 220 (2003) 3.

[25] H. Nibbelke, M.A.J. Campman, J.H.B.J. Hoebink, G.B. Marin, J. Catal. 171 (1997) 358.
[26] G. Kim, Ind. Eng. Chem. Prod. Res. Dev. 21 (1982) 267.

[27] C. Li, Y. Sakata, T. Arai, K. Domen, K. Maruya, T. Onishi, J. Chem. Soc. Faraday Trans. 1 (85) (1989) 1451.

[28] E. Odier, Y. Schuurman, K. Barral, C. Mirodatos, Stud. Surf. Sci. Catal. 147 (2004) 79.

[29] A. Trovarelli, G. Dolcetti, C. de Leitenburg, J. Kašpar, P. Finetti, A. Santoni, J. Chem. Soc. Faraday Trans. 88 (1992) 1319.

[30] C. de Leitenburg, A. Trovarelli, J. Catal. 156 (1995) 174

[31] C. de Leitenburg, A. Trovarelli, J. Kašpar, J. Catal. 166 (1997) 107.

[32] A. Galdikas, D. Duprez, C. Descorme, Appl. Surf. Sci. 236 (2004) 355.

[33] T. Engel, G. Ertl, Adv. Catal. 28 (1979) 1.

[34] L.F. Razon, R.A. Schmitz, Catal. Rev. Sci. Eng. 28 (1986) 89.

[35] B.W. Wojciechowski, S.P. Aspey, Appl. Catal. A: Gen. 190 (2000) 1.

[36] S. Salomons, R.E. Hayes, M. Votsmeier, A. Drochner, H. Vogel, S. Malmberg, J. Gieshoff, Appl. Catal. B: Environ. 70 (2007) 305.

[37] M.P. Harold, M.E. Garske, J. Catal. 127 (1991) 524

[38] H.C. Yao, Y.F. Yu Yao, J. Catal. 86 (1984) 254.

[39] A.B. Mhadeshwar, D.G. Vlachos, Combust. Flame 142 (2005) 289.

[40] R.H. Nibbelke, A.J.L. Nievergeld, J.H.B.J. Hoebink, G.B. Marin, Appl. Catal. B: Environ. 19 (1998) 245.

[41] J.A. Dumesic, D.F. Rudd, L.M. Aparicio, J.E. Rekoske, A.A. Trevino, The Microkinetics of Heterogeneous Catalysis, American Chemical Society, Washington, DC, 1993.

[42] A.B. Mhadeshwar, H. Wang, D.G. Vlachos, J. Phys. Chem. B 107 (2003) 12721

[43] O. Thinon, K. Rachedi, F. Diehl, P. Avenier, Y. Schuurman, Top. Catal. 52 (2009) 1940.

[44] C.T. Campbell, Top. Catal. 1 (1994) 353.

[45] C. Stegelmann, A. Andreasen, C.T. Campbell, J. Am. Chem. Soc. 131 (2009) 8077.

[46] F. Duprat, Chem. Eng. Sci. 57 (2002) 901. 